Trivent Publishing

(C) Trivent (2019)

Available online at http://trivent-publishing.eu/

\title{
Prostitution in Urban Brothels in Late Medieval Austria
}

\author{
Michael M. Hammer \\ University College of Teacher Education Styria, \\ Austria, michael1.hammer@phst.at
}

\section{Abstract}

Municipal authorities officially established urban brothels in late medieval Austria as a necessary evil in order to control the lust of unmarried men and thus protect women from sexual abuse. During the course of the fifteenth century, brothels began to flourish in cities all over Austria until their abolition during the period of the Reformation and Counter-Reformation in the sixteenth century. This paper focuses in particular on four Tyrolean brothels (Bolzano, Hall, Innsbruck and Merano) and on the relevant sources of late medieval brothels in general, taking into account both their potential as well as their limitations. Certain sources allow a closer look into the daily life of both the prostitutes and the brothel keepers. Court cases sometimes provide information about the names of people and their daily business. Second, it concentrates on everyday life in these brothels. Prostitution was handled as a "safety valve" to provide a sexual outlet for unmarried men; they are, therefore, an instrument to guarantee the pax urbana. Furthermore, the brothels provided the possibility of controlling 
extramarital sexuality. For this reason, the municipal authorities also tried to prohibit clandestine types of prostitution - no doubt to also protect their own financial interests.

Keywords: Prostitution; prostitutes; brothels; Frauenhaus; sexuality; urban history; Austria; Tyrol; fifteenth/sixteenth century. 


\title{
Prostitution in Urban Brothels in Late Medieval Austria
}

\author{
Michael M. Hammer \\ University College of Teacher Education, Styria, Austria
}

\section{Introduction}

Prostitution in urban brothels of late medieval Austria has been largely neglected by research for a considerable time. German scholars ${ }^{1}$ mention single cases of brothels in Austria while some publications put emphasis on regional studies of urban brothels such as those in Vienna, Wiener Neustadt ${ }^{2}$ or Judenburg ${ }^{3}$. Due to the absence of an extensive study on the Austrian system of brothels, I have dedicated my doctoral dissertation to this subject. ${ }^{4}$ The following paper will summarize the main results of this study, aiming to identify the main problems involved in researching urban brothels in Austria in the Middle Ages.

\footnotetext{
1 Peter Schuster, Das Frauenhaus. Städtische Bordelle in Deutschland (1350-1600) (Paderborn: Schöningh, 1992); Beate Schuster, Die freien Frauen. Dirnen und Frauenhäuser im 15. und 16. Jahrbundert (Frankfurt am Main: Campus-Verl., 1995).

2 B. Rath, "Prostitution und spätmittelalterliche Gesellschaft im österreichischsüddeutschen Raum", in Frau und spätmittelalterlicher Alltag, ed. Heinrich Appelt (Vienna: Verl. d. Österr. Akad. d. Wiss., 1986), 553-571.

3 Sonnleitner, K., “'Sündhaftes' Geld für fromme Stiftungen. Urkunden zum Frauenhaus in der steirischen Stadt Judenburg im 15. Jahrhundert", in Stadt, Handwerk, Armut. Eine kommentierte Quellensammlung zur Geschichte der Frühen Neuzeit. Helmut Bräuer zum 70. Geburtstag zugeeignet, ed. Katrin Keller et al. (Leipzig: Leipziger Univ.-Verl., 2008), 385-392.

${ }^{4}$ Michael M. Hammer, "Von gemeinen Frauen und guten Fräulein: Das österreichische Frauenhauswesen im Spätmittelalter und in der Frühen Neuzeit." (PhD diss., University of Graz, 2016).
} 


\section{The establishment of urban brothels in late medieval Austria}

Throughout the fifteenth century, municipal authorities all over Austria established urban brothels under their control for the benefit of the pax urbana. St. Augustine identified prostitution as a necessary evil which would prevent respectable women from being sexually abused. ${ }^{5}$ The libido of unmarried men was considered a great threat to the honourable women in the city. The physical and sexual integrity of a woman was what defined her honour - virginity (or monogamy with a married partner) was the honourable way of life. On the other hand, there were many unmarried men in urban societies. Either they were prohibited from marriage due to their social status as servants in the familia of their patron, or they were unmarried for other reasons, such as a poor financial status. The civic authorities saw the need for a safety valve for these lustful unmarried men in order to minimize the threat of sexual abuse. The following example from Bolzano shows how the authorities legitimized the establishment of a new brothel (the Frauenhaus) in 1472:

von des frawenhaws wegen

ist mit Ratt erfund(en) das fraw(e)nhaws halb(e)n das das gepawt wird nach notturfft vnd mit ai(ne)n pawmaist(er) $\mathrm{v}(\mathrm{er}) \operatorname{seh}(\mathrm{e}) \mathrm{n}$ als mit dem Jost Ortlieb dez gepet(e)n wird sich des anzunem(en) vnd das paw zuend damit die gut(e)n frawlein ir wonung da gehab(e)n mug(e)n damit mer(er) ergernusz v(er)mit(e)n wird. ${ }^{6}$

The civic council decrees the establishment of a Franenhaus which would house the city's own prostitutes, the so-called "gute Fräulein," in order to prevent greater evil. The town authorities do not concretize what they actually meant by this evil, but it was a common pattern to establish urban brothels for the benefit of urban peace.

5 "Quid sordidus, quid inanius decoris et turpitudinis plenius meretricibus, lenonibus, caeterisque hoc genus pestibus dici potest. [...] Aufer meretrices de rebus humanis, turbaveris omnia libidinibus." Augustinus, "De ordine", in Patrologia latina, vol. 32, ed. Jacques Paul Migne (Paris, 1841), 1000.

${ }^{6}$ Stadtarchiv Bozen, ms. 2, fol. 2. Translation: The council (of Bolzano) instructs the builder Jost Ortlieb to put up a Franenhaus, as it is a necessity for the good Fräulein (plural) to have an accommodation, in order to prevent more (public) offence. 


\section{The research of late medieval brothels: prospects and limitations}

What are the prospects and limitations of researching urban brothels in the late medieval period? Unfortunately, there are more questions than answers in this research. In Austria, at least thirteen sites of urban brothels can be identified: (from the east to the west) Vienna, Klosterneuburg, Korneuburg, Wiener Neustadt, Krems, Graz, Judenburg, Salzburg, Hall, Innsbruck, Bolzano, Merano and Feldkirch (see Fig. 1). ${ }^{7}$

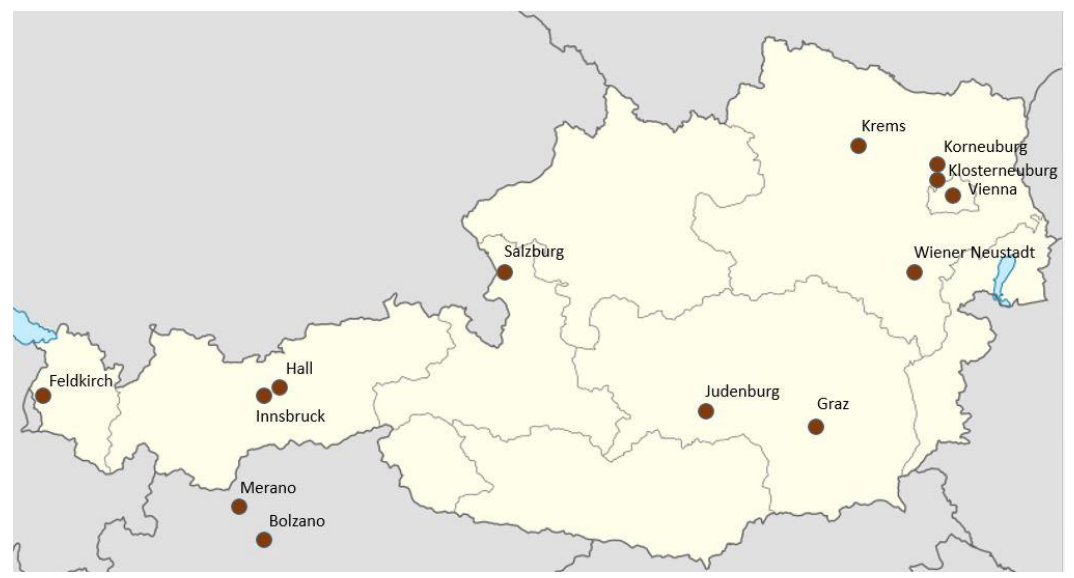

Fig. 1. Former late medieval sites of brothels in Austria

Older city chronicles will sometimes mention the existence of a medieval brothel. Although the authors of the nineteenth and early twentieth century often dismissed the Frauenbäuser as a moral lapse of a more or less immoral time, ${ }^{8}$ they give a first hint an urban brothel existing in the respective city. As the Frauenhaus was a solely urban phenomenon, sources and records are almost exclusive to town archives. Records from the civic council, account books and court records are the main sources for research. As the mayor's office

\footnotetext{
${ }^{7}$ Hammer, Von gemeinen Frauen und guten Fräulein, 162-166.

${ }^{8}$ For example Franz Seraph Hügel, Zur Geschichte, Statistik und Regelung der Prostitution (Wien: Zamarski \& Dittmarsch, 1865) or Josef Schrank, Geschichte der Prostitution in Wien (Wien: Eigenverlag, 1886).
} 
officially owned the Frauenhaus, the council records provide the most data. They give information about the very establishment of the brothels, the lease of the brothel to a new brothel keeper and other measures taken to ensure that it remained functional. The account books of civic artisans on the other hand will sometimes provide detailed information about the interior of an urban brothel; for instance, they could mention whether the prostitutes had their own chambers in which they lived and worked. The brothel keeper served his guests food and drink in a public room which also introduced the client to potential intercourse with the prostitutes. The account books even give information in some cases about the number of beds, chairs and ovens. ${ }^{9}$ The urban brothel was not just a site of the sex trade, but also a place for convivial gatherings. Due to this fact, there are fortunately some mentions of urban brothels and their everyday life in court records. The consumption of wine sometimes led to conflicts and fights. Furthermore, conflicts between the prostitutes and the brothel keeper are also to be found in court records and occasionally mention specific names. ${ }^{10}$

Most of the sources about the Austrian brothel system come from the Tyrolean town archives. There is evidence for the existence of at least four brothels in this region, one each in Bolzano, Hall, Innsbruck and Merano. Since these sites provide the most ample information, they will be examined in greater detail here.

\section{Reasons and bases for the establishment of urban brothels in Tyrol}

The origins of the brothel in Bolzano in 1472 have already been mentioned. The city was an important centre of commerce and trade. Due to its geographical location, numerous Italian merchants passed through the town on their way to Germany. Many foreign merchants also meant many men. The city council may not just have had in mind the potential threat of the pax urbana due to the unsatisfied lust of men,

\footnotetext{
${ }^{9}$ More detailed information about the interior equipment of brothels is documented for example in Hall (Stadtarchiv Hall in Tirol, Raitbuch 3, fol. 170'-179), Merano (Stadtarchiv Meran, BAR 5, fol. 15') or Salzburg (Stadtarchiv Salzburg, BU 257 fol. 236).

${ }^{10}$ Hammer, Von gemeinen Frauen und guten Fräulein, 13-16.
} 
but also a potential source of income. However, financial interests were never an official reason for establishing an urban brothel. Nevertheless, the economic benefit of the brothel was an important factor for its continuing existence throughout the following decades.

Not only were foreign merchants the main clients of the prostitutes but also unmarried inhabitants of the city. The city of Hall, known for its salt industry, gives a more concrete example. The numerous (unmarried) labourers in the salt mines were potential clients of a brothel in Hall. We do not know the concrete reasons it was established, but the account books of Hall attest to the existence of an urban brothel by $1455 .{ }^{11}$ This is also interesting because the brothel of Innsbruck was only a few kilometres away. This seems to prove that the civic leaders of Hall had their own financial interest in a brothel within the city walls.

Due to its status as a residence for the Habsburgs, Innsbruck was also a magnet for both artisans and foreign travellers to the emperor's court. By the late medieval and early modern period, the city lived from the exchange of goods and the passage of foreign passengers and guests. ${ }^{12}$ The first evidence of a Frauenhaus in Innsbruck dates back to 1465. ${ }^{13}$ Little is known about this brothel but it appears that its establishment was due to the city's status as a centre of trade and as an imperial residence.

Similar conditions existed in the city of Merano, an important hub for trade between Germany and Italy as well as a residence of the sovereign. In 1449, the municipal authorities established a local Frauenhaus in Merano. They leased it to an inhabitant of the city, Hans Raperswyler, the new tenant of the brothel. The authorities also established terms and conditions for the lease: the brothel keeper was supposed to house exclusively "common daughters" ("gemayn toechter") and nobody else. The prostitutes were permitted to buy wine and food from a local innkeeper during the day. At night, they had to stay in the brothel and could not look for clients in the streets. ${ }^{14}$ This constraint

\footnotetext{
11 Max Straganz, Hall in Tirol. Ein Beitrag zur Geschichte des tirolischen Städtewesens, Vol. 1 (Innsbruck: Schwick, 1903), 220.

12 Otto Stolz, Geschichte der Stadt Innsbruck (Innsbruck: Tyrolia-Verl., 1959), 279.

13 Stadtarchiv Innsbruck, Urkunde 389.

${ }^{14}$ Cölestin Stampfer, Geschichte von Meran, der alten Hauptstadt Tirols (Innsbruck: Wagner, 1889), 52 .
} 
also shows another aspect of the brothel system in the late medieval city: the Frauenhaus was also an instrument to restrict prostitution in the streets. The authorities tried to prohibit this clandestine form of prostitution for it disturbed the society's sense of morality. In addition, with the establishment of their own urban brothels, the authorities formerly the owners - wanted to eliminate competition in order to increase the profit of the brothel. Prostitution was a necessary evil and therefore something to be controlled. Any other deviant form of sexuality was banned. The same was true in Bolzano, for example, where clandestine prostitutes were arrested and sent to the brothel if they were found in the streets or in taverns. ${ }^{15}$

\section{Everyday life in the brothel}

\section{Order and deviance}

The punishment for clandestine prostitution also led to conflict. The court records occasionally document these conflicts. One very interesting case occurs in 1471: Elsa Stecklin, an inhabitant of Merano, was found in a compromising situation in a dubious tavern. Elsa, an unmarried woman, was eating and drinking with another man. This was reason enough to suspect her of being an illegal prostitute. Therefore, the brothel keeper and his prostitutes took her to the brothel. However, Elsa Stecklin was not brought to the Franenhaus discreetly, but in a public and well-prepared procession. ${ }^{16}$ This so-called "Rügebrauch" was one of the measures taken against illegal prostitution. ${ }^{17}$ The women taken to the brothel lost their honour - a severe punishment for their deviant way of life. Elsa Stecklin, however, considered herself innocent. She claimed that a certain Heinrich Stier wanted revenge because she had refused "to fulfil his will". ${ }^{18}$ Unfortunately, the history of the personal

\footnotetext{
15 Stadtarchiv Bozen, ms. 175, fol. 13/12.

16 Landesarchiv Tirol, Mikrofilm 555/2/fol. 88'; Hammer, Von gemeinen Frauen und guten Fräulein, 236-238.

17 See B. Schuster, "Wer gehört ins Frauenhaus? Rügebräuche und städtische Sittlichkeitspolitik im 15. und 16. Jahrhundert", in Institutionen und Ereignis. Über historische Praktiken und Vorstellungen gesellschaftlichen Ordnens, ed. Reinhard Blänker et al.(Göttingen: Vandenhœek \& Ruprecht, 1998), 185-252.

18 " $[. .$.$] het ich dein will(e)n pfleg(et), so hettest du mir daz nit getan." Landesarchiv$ Tirol, Mikrofilm 555/2/fol. 88.'
} 
relationship between Stecklin and Stier remains unknown, as well as the outcome of her complaint to the court. What can be determined is that - in dubio pro reo - the suspected clandestine prostitutes were discharged from the accusations when they could not be proven. Not only common inhabitants initiated such reprimands, but also the mayor himself could order such measures. In 1480, Bolzano resident Margret Pewrlein sent a request to the Archduke asking for his help in reclaiming her honour. She had been taken to the brothel on the mayor's order even though she had claimed herself innocent. Her request was successful and the Archduke ordered an inquiry into this case. ${ }^{19}$

\section{Economic interests and potential conflicts}

As already mentioned, the economic prospects of a brothel were also an important aspect for the municipal authorities. Economic reasons may not have been the main interest for establishing a brothel, but they were definitely the reason for its continuing existence. Some scholars promote the thesis that financial interests played - if at all - a marginal role for the existence of urban brothels. ${ }^{20}$ In some cities, this is simply not the case. In Bolzano, for example, the hangman Meister Conrat appealed to the Archduke of Tyrol and asked his majesty to transfer to him the right to house the prostitutes of Bolzano because a fire had destroyed the old brothel. The town authorities, according to Meister Conrat, wanted to reconstruct the Frauenhaus because of its (high) revenues. The Archduke decided in favour of the hangman because he saw no need for a new brothel when there was already a suitable house for the prostitutes elsewhere. ${ }^{21}$ The hangman eventually became the new brothel keeper but after only a few years, the mayor's office had regained its control over the Frauenhaus. ${ }^{22}$ The revenues of the brothel in Bolzano were the highest in comparison to all other urban brothels in Austria. It is no surprise, therefore, that the city council sought control over this Frauenhaus.

\footnotetext{
19 Tiroler Landesmuseum Ferdinandeum Innsbruck, FB 4337, Urkunde 5.

20 P. Schuster, Das Frauenhaus, 45; B. Schuster, Die freien Frauen, 94-95.

${ }^{21}$ Landesarchiv Tirol, Urkunde I 4237/2.

22 Hammer, Von gemeinen Frauen und guten Fräulein, 212-213.
} 


\section{Customers, costs and income}

Where did the money come from? Urban brothels were a restricted area for sex trade. Brothel keepers only granted entrance to certain men; others were prohibited. Married men, clerics or Jews were not permitted to have sex with a common prostitute in the Frauenhaus. As a married man had no right to express his sexuality freely but only within marriage, adultery with a prostitute was prohibited and actually punished as evidenced in numerous court records. It was forbidden for clerics and Jews to have sex with a (Christian) prostitute for religious reasons. Nevertheless, sources mention several sexual relationships between illegal clients and prostitutes. While the Church usually punished transgressing clerics, Jewish men faced the death penalty when their sexual intercourse with a Christian woman was revealed. ${ }^{23}$

The brothel, however, never lacked customers. Many male inhabitants in the cities were unmarried due to their social and economic status. In addition, the masses of foreigners that passed through the cities were the main clients of the Frauenhaus. The costs of a service in the brothel were likely adjusted to the average wages of a journeyman. ${ }^{24}$ The income of the sex work was divided into three parts: one part remained in the hands of the prostitute, one part was given to the brothel keeper and the third part was paid to the mayor's office..$^{25}$ The brothel keeper could also make some extra money serving wine and food. The Framenhaus was therefore not only a site for sex trade but also a place for social gatherings.

The prostitutes: economic prospects, social status and working conditions

As only one third of the earnings of the sex work actually remained in the hands of the prostitutes, many could not afford the costs of living and working in the Frauenhaus. In general, the vast majority of all common women in the brothel lived under great economic pressure. Most women could not afford the rent and as a result often got into debt. Sometimes they even had to buy the clothing from the brothel

\footnotetext{
23 P. Schuster, Das Franenhaus, 117.

24 Ibid., 112-114.

${ }^{25}$ Hammer, Von gemeinen Frauen und guten Fräulein, 117-118.
} 
keeper, which caused more and more debt; the prostitutes of the Frauenhaus lived in a state of continual exploitation. Peter Schuster equates working conditions in the urban brothels with slavery. ${ }^{26} \mathrm{It}$ seems that the working conditions deteriorated more and more, so much so that the town authorities had to intervene. The authorities set up regulations for the brothels in some cities. The "Franenhausordnung" was supposed to guarantee basic rights to the prostitutes in order to prevent exploitation. The concept of such regulations originated from the Christian idea of the freedom of men. ${ }^{27}$

The situation for the common women, however, did not improve significantly under these regulations. Prostitutes often had no way out of the brothel due to their debts. Again, the city and the church had to deal with the problem and tried to help women on their way out of prostitution. They encouraged craftsmen (mostly journeymen) to marry a prostitute out of the brothel. In return, they could sometimes be given citizenship of the city, like in the case of Nuremberg. ${ }^{28}$ Prostitutes had to give a token payment in order to pay their debts. In some cases, pious donations from burghers cleared the debts of these prostitutes. Some cities even installed their own institutions for repentant prostitutes. In Vienna, the Duke, the church and the burghers funded the construction of a house for repentant prostitutes in 1383/84, ${ }^{29}$ exclusively for prostitutes from the Frauenhaus. This illustrates the lack of other realistic opportunities for women who wanted to leave the brothel. Nevertheless, most of the cities did not have such institutions.

The acceptance of prostitutes within the city walls and the efforts taken to ease the way out of prostitution should not hide the fact that prostitutes, in general, were on the lower social scale of urban society. In many medieval cities, common women had to wear special clothing

\footnotetext{
26 P. Schuster, Das Frauenhaus, 90-91.

27 See the regulations in Nuremberg: Joseph Baader, Nürnberger Polizeiordnungen aus dem XIII. bis XV. Jabrbundert (Stuttgart: Literarischer Verein, 1861), 117-121.

28 B. Schuster, "Frauenhandel und Frauenhäuser im 15. und 16. Jahrhundert." Vierteljabrschrift für Sozial- und Wirtschaftsgeschichte 78/2 (1991): 186; P. Schuster, "Lebensbedingungen der Prostituierten in der spätmittelalterlichen Stadt," in Frauen in der Stadt, ed. Günther Hödl et al. (Linz: Österr. Arbeitskreis für Stadtgeschichtsforschung, 2003), 285.

29 Barbara Schedl, Klosterleben und Stadtkultur im mittelalterlichen Wien. Zur Architektur religiöser Frauenkommunitäten (Innsbruck: StudienVerl., 2009), 257; Schrank, Geschichte der Prostitution, 78-79.
} 
or accessories that labelled them as prostitutes. In Vienna, for example, they had to put yellow stripes on their clothes. ${ }^{30}$ The colour red was also prominent for prostitutes. Furthermore, they were not allowed to wear precious jewellery in order to distinguish them from honourable women. ${ }^{31}$ The civic authorities sometimes did not want the women to be socially mobile and it was impossible for prostitutes to gain citizenship. In the fourteenth century they could even be beaten without consequences for the aggressor. ${ }^{32}$ Although the regulations taken by the town authorities in the fifteenth century prohibited any violence against prostitutes, their social status did not improve significantly. On a few special occasions, prostitutes played an exclusive role in the city life. During special festivities, for example the entry of a sovereign, the women of the Frauenhaus were invited to welcome the ruler. ${ }^{33}$ However, the other inhabitants, mostly the honourable burghers, were always eager to set clear boundaries between them and the common folk or marginal groups.

The urban brothels generally appear in less prestigious sites of the city. ${ }^{34}$ Usually, they were located near the city walls. In Graz, the Frauenhaus was near the walls in the Jewish quarter. ${ }^{35}$ In Vienna, one Franenhaus was situated in an area with a bad reputation, while the other two did not even have the privilege of being secured by the city walls they were located outside the walls and finally destroyed in 1529 during a siege. The Frauenhaus of Wiener Neustadt was also destroyed during a siege. ${ }^{36}$ If the authorities had interest in a functioning brothel, they constructed them within the city walls. This, however, sometimes bothered the inhabitants: In 1501, documents from the municipal authorities of Innsbruck mention the construction of a (new?) brothel.

30 Anton von Geusau, Geschichte der Belagerung Wiens durch den König Mathias von Hungarn in den Jahren 1484 und 1585 (Vienna, 1805), 95-96.

31 Hammer, Von gemeinen Frauen und guten Fräulein, 58-59.

32 For example in Salzburg, see Klemens Stadler, Beiträge zur Rechtsgeschichte der Stadt Salz̧burg im Mittelalter (Hirschenhausen: Südostbayerische Heimatstudien, 1934), 118.

33 Ibid., 60-61.

34 Ibid., 96-98; B. Schuster, Die freien Frauen, 98-99; see also the papers of Christopher Mielke and Gordan Ravancic on the location of brothels within medieval cities in this volume.

35 Ibid., 199.

36 Joseph Chmel, Actenstücke und Briefe zur Geschichte des Hauses Habsburg im Zeitalter Maximilian's I., vol. 2 (Wien: kaiserlich-königliche Hof- und Staatsdruckerei, 1855), 620. 
By 1511, Emperor Maximilian had ordered a relocation of the Frauenhaus to another, probably less honourable part of the city. However, the city council doubted the purpose of this order and did not follow it. ${ }^{37}$ It appears that the brothel of Innsbruck had its solid place within the city and the society. In 1527, the authorities received another order to relocate the brothel. Archduke Ferdinand was bothered by the location of the brothel. He wanted it to be relocated, ideally beyond the city walls. By this time, the attitude towards prostitution and brothels had already begun to change.

\section{The end of an era: the abolishment of urban brothels in the sixteenth century}

The change of morals and attitude was one of the causes for the closing of all urban brothels in German-speaking lands. The Reformation (and Counter-Reformation) and problems with disease, especially syphilis, caused a shift in this attitude. The crisis of the late medieval period put pressure on the brothels. People started being bothered by deviant ways of life again. During the sixteenth century, all German brothels were closed either voluntarily or by the force of the society and/or the civic authorities. A very interesting example of this occurs in Bolzano. As already mentioned, the Frauenhaus of Bolzano was one of the greatest brothels in Austria. The mayor had a verifiable (financial) interest in "his" brothel. Given this interest, it is even more remarkable that the mayor's office was so eager to shut down the brothel in 1540. The council had already decided on the closure of the Franenhaus in 1539, but the brothel keeper, Katharina, did not bow to this decision. She did not close the brothel as it would have destroyed her livelihood. In response, the council threatened to put her in prison for 10 days and to expel her from the city afterwards. Katharina finally gave in and closed the brothel. ${ }^{38}$ It is unknown not only what happened to her or what happened to the prostitutes that had been working there. The prostitutes probably worked illegally and in secret just as it was before the brothels under the control of the cities were created. The "problem" of prostitution, as it was identified by the reformers of the

37 C. Lorenzi, "Prostituierte in Innsbruck," in Frauenleben in Innsbruck. Ein bistorisches Stadt-und Reisebuch, ed. Ellinor Forster et al. (Salzburg: Anton Pustet, 2003), 64.

${ }^{38}$ Hammer, Von gemeinen Frauen und guten Fräulein, 216-218. 
Christian faith in the sixteenth century, could not be abolished. The Frauenbäuser, as controlled and regulated institutions of prostitution were never opened again.

\section{References}

Unpublished primary sources

Landesarchiv Tirol, Mikrofilm 555/2; Urkunde I 4237/2.

Stadtarchiv Bozen, ms. 2; 175.

Stadtarchiv Hall in Tirol, Raitbuch 3.

Stadtarchiv Innsbruck, Urkunde 389.

Stadtarchiv Meran, BAR 5.

Stadtarchiv Salzburg, BU 257.

Tiroler Landesmuseum Ferdinandeum Innsbruck, FB 4337, Urkunde 5.

\section{Secondary Sources}

Augustinus. "De ordine." In Patrologia latina vol. 32, ed. Jacques Paul Migne, 977-1020. Paris, 1841.

Baader, Joseph. Nürnberger Polizeiordnungen aus dem XIII. bis XV. Jabrbundert. Stuttgart: Literarischer Verein, 1861.

Chmel, Joseph. Actenstïcke und Briefe zur Geschicbte des Hauses Habsburg im Zeitalter Maximilian's I., vol. 2. Vienna: kaiserlich-königliche Hofund Staatsdruckerei, 1855.

Hammer, Michael M. Von gemeinen Frauen und guten Fräulein:

Das österreichische Frauenhauswesen im Spätmittelalter und in der Frühen Neuzeit. PhD diss., University of Graz, 2016.

Hügel, Franz S. Zur Geschichte, Statistik und Regelung der Prostitution. Vienna: Zamarski \& Dittmarsch, 1865.

Lorenzi, C. "Prostituierte in Innsbruck." In Frauenleben in Innsbruck. Ein bistorisches Stadt- und Reisebuch, ed. Ellinor Forster et al, 64-74. Salzburg: Anton Pustet, 2003.

Rath, B. "Prostitution und spätmittelalterliche Gesellschaft im österreichisch-süddeutschen Raum.” In Frau und spätmittelalterlicher Alltag, ed. Heinrich Appelt, 553-571. Vienna: Verl. d. Österr. Akad. d. Wiss., 1986. 
Schedl, Barbara. Klosterleben und Stadtkultur im mittelalterlichen Wien. Zur Architektur religiöser Frauenkommunitäten. Innsbruck: StudienVerl., 2009.

Sonnleitner, K. “'Sündhaftes' Geld für fromme Stiftungen. Urkunden zum Frauenhaus in der steirischen Stadt Judenburg im 15. Jahrhundert." In Stadt, Handwerk, Armut. Eine kommentierte Quellensammlung zur Geschichte der Frühen Neuzeit. Helmut Bräuer zum 70. Geburtstag zugeeignet, ed. Katrin Keller et al., 385-392. Leipzig: Leipziger Univ.-Verl., 2008.

Schrank, Josef. Geschichte der Prostitution in Wien. Vienna: Eigenverlag, 1886.

Schuster, Beate. Die freien Frauen. Dirnen und Frauenbäuser im 15. und 16. Jahrbundert. Frankfurt am Main: Campus-Verl., 1995. . "Frauenhandel und Frauenhäuser im 15. und 16. Jahrhundert." Vierteljahrschrift für Sozial- und Wirtschaftsgeschichte 78/2 (1991): 172-189. ."Wer gehört ins Frauenhaus? Rügebräuche und städtische Sittlichkeitspolitik im 15. und 16. Jahrhundert." In Institutionen und Ereignis. Über historische Praktiken und Vorstellungen gesellschaftlichen Ordnens, ed. Reinhard Blänker et al., 185-252. Göttingen: Vandenhœek \& Ruprecht, 1998.

Schuster, Peter. Das Frauenhaus. Städtische Bordelle in Deutschland (13501600). Paderborn: Schöningh, 1992. ."Lebensbedingungen der Prostituierten in der spätmittelalterlichen Stadt.” In Frauen in der Stadt, ed. Günther Hödl et al., 265-291. Linz: Österr. Arbeitskreis für Stadtgeschichtsforschung, 2003.

Stadler, Klemens. Beiträge zur Rechtsgeschichte der Stadt Salz̧burg im Mittelalter. Hirschenhausen: Südostbayerische Heimatstudien, 1934. Stampfer, Cölestin. Geschichte von Meran, der alten Hauptstadt Tirols.

Innsbruck: Wagner, 1889.

Stolz, Otto. Geschichte der Stadt Innsbruck. Innsbruck: Tyrolia-Verl., 1959. Straganz, Max. Hall in Tirol. Ein Beitrag zur Geschichte des tirolischen

Städtewesens, vol. 1. Innsbruck: Schwick, 1903.

von Geusau, Anton. Geschichte der Belagerung Wiens durch den König Mathias von Hungarn in den Jahren 1484 und 1585. Vienna, 1805. 